\title{
Banyu Moto - 'The Tears' by Nella Kharisma Featuring Dory Harsa as Analyzed in the Context of Hyperreality
}

\author{
Jordy Mesakh ${ }^{1, *}$ Susilo Pradoko ${ }^{2}$
}

\author{
${ }^{1}$ Graduate School of Art Education, Yogyakarta State University, Yogyakarta 55281, Indonesia \\ ${ }^{2}$ Faculty of Languages and Arts, Yogyakarta State University, Yogyakarta 55281, Indonesia \\ ${ }^{*}$ Corresponding author. Email: jordymesakh86@gmail.com
}

\begin{abstract}
This paper reviews the song titled Banyu Moto (the Tears) sung by Nella Kharisma featuring Dory Harsa in the context of hyperreality. The study aims to explore the benefits of hyperreality in the music creative industry in the postmodern era, especially for the popular disco-dangdut song titled Banyu Moto (the Tears). This research is a qualitative research using multimodality based on social semiotics. The study revealed that the video clip of Banyu Moto depicts two singers who are in a duet with a romantic song and passion. Their act seems real and is done to convince the audience that their video is about real-life love and is done with passion which would make the audience in the hyperreal context assume that what happens in the video is a reality. This study concludes that the song contains hyperreal elements as seen in the media of delivery to lever up the popularity of the song titled Banyu Moto and both singers, Nella Kharisma and Dory Harsa.
\end{abstract}

Keywords: Hyperreality, Disco-Dangdut, the Song Titled Banyu Moto (The Tears)

\section{INTRODUCTION}

The video of 'Banyu Moto' really convinces the viewers that the singers of the song are a couple in real life. The enthusiasm of the audience even comes to the extent that they wish a joyful, eternal love life for the singers. The audience is made to believe in what they see in the video. According to Baudrillard [1], the unrealistic acts represent the concept of hyperreality.

Hyperreality is a concept in postmodernism in a world where the existing measures of reality can no longer be held [1]. The reality of the world in its construction cannot be separated from hyper-sign production and free acts. Therefore, the world of hyperreality can be seen as a manipulation of the world of reality through the manipulation of signs. The manipulation can be extreme that the signs do not represent the existing reality that needs to be portrayed. Hyperreality creates a condition where simulation is mixed with authenticity, past mingles with present, facts are confused with manipulation, signs merge with reality, and lies are interwoven with truth [1].
The creation of the cultural world today follows a production model called simulation-creation of a real model without origin or reality [1]. Humans are trapped in a false reality or fantasy space. The pseudo-reality space is the antithetic space of the representation itself. In fact, humans are actually in the realm of reality, where the difference between reality and delusion or true and false is considerably minor, and humans live in a real fictional space [2]. A media or fantasy world is actually as real as history or ethics lessons in school, because both offer information and shape a person's attitude and lifestyle.

In this modern era, information media and information technology play a major role in the construction of human socio-cultural reality [3]. Human thoughts are also influenced by technology and information media. The development of technology also forms reactions and the construction of social and cultural realities of humans in a realm that looks real even though it is not. Mass media also shapes reality through simulation models (images, codes, and signs) capable of creating a fantastic (hyper) reality [1]. Hyperreality will obscure reality and cannot describe the reality that occurs. It also contains messages, signs and 
meanings, but these elements cannot be properly reflected and understood by the audience.

Disco-dangdut has entered the era of competition in the creative industry in the domestic music sector. The large number of Malay dangdut music groups and the excessive fanaticism towards dangdut music is a sign that disco-dangdut is a promising field in the creative industry. The law of commodities automatically makes the consumers kings. It respects the highest value of the individuals, who satisfy the needs, aspirations, wants and desires of others as fully and as possible, giving everyone the opportunity to find pleasure with themselves (ecstasy). Ecstasy is a mental and spiritual condition when someone is in a constant circular movement, until the reality loses all meaning, and there is a void in their mind [1]. Similar to disco-dangdut music, the socializing process that grows in the community indicates that music is an entertainment which is also classified as a cultural reality.

The researchers consider that it is important to raise the context of the hyperreality of disco-dangdut in the Banyu Moto video, a song sung by Nella Kharisma featuring Dory Harsa to see how a singer uses the media to help convey the meaning and message contained in the lyrics, and win the hearts of music lovers from other genres.

\section{LITERATURE REVIEW}

\subsection{The Postmodern Era}

The modern history which is considered to have replaced the modern era is often called postmodern [4]. New ways of thinking and entirely new thinking techniques are also present in it. It is also believed that globalization was born from critical reflection of postmodernism [4].

Postmodern culture is based on several assumptions about the relationship between humans and media, originally created by Marshall McLuhan [1]. Mass media represents a new era in which old forms of production and consumption have given way to a new world of communication [1]. Therefore, there is a discussion about 'media' which means that it cannot be separated from the word 'mass', and one of the important functions of postmodern culture is mass media. Apart from blurring boundaries, the media have also interfered with the public and private spheres.

Deconstruction is one of the signs of modern communication, namely the dismantling of various codes that build language communities, and leaving them in a state of uncertainty. As a result, there are more communication patterns of signs than meanings, there are more significant signs than what is indicated, images are more reinforced than truth, and there are more simulacrums than facts. Celebrating events that are insignificant, trivial and not urgent has become a habit or trend for people who live in the postmodern era. This has made discussions and dialogues become communication discourses [5].

\subsection{Hyperreality}

In the context of hyperreality, the world is characterized by the alternation of reproduction of objects that are simulacrum, which are either uprooted from past social realities, or have absolutely no social reality as their reference. In such a universe, subjects as consumers are directed into hyperreal 'spatial experiences' - alternating experiences of 'appearances' in the space provided, mixing and combining reality with hallucinations and nostalgia as well as fiction and fantasy, and these result in the difficulty in distinguishing between one event or object and another. Nostalgia and science fiction are two aspects that are hyperreality emphasized by Baudrillard [6].

'Hyperreality' in communication is caused by the manipulation and distortion of meaning in communication $[1 \& 6]$. A production house can create a remarkable piece, which makes it difficult to distinguish what is real from what is merely spectacle. The plot that seems real and alive can also be fully controlled by the production house which is often referred to as dramatization.

The majority of reality shows that the audience views are no longer original real-life shows but only entertainment and the truth of those shows can be manipulated by the media. All events can be considered as mere hyperreality. Hyperreality has many impacts on humans in real life. One of the most significant impacts is that humans would not believe in the truth. Many humans are more comfortable in a pseudo fantasy space which is easier to control by their way of thinking. Simulation, which is a production model for emergence in consumer society, is no longer related to the duplication of a duplicated object or event, but rather the creation through the model of something real without origin (hyperreality) [7]. The duplication is no longer just reality, but a fantasy. Since fantasy can be simulated into something that seems real, the difference between reality and fantasy no longer exists. In the postmodern era, the principle of simulation has become a priority, because the role of reproduction, both from the technological side and even to knowledge and information media, plays a bigger role in replacing the principle of production, and the human communication process is carried out by using signs and images.

Jean Baudrillard, who discusses The Precession of Simulacra in his book Simulacra and Simulations, suggests that the tendency of using political images leads to simulations of reality [8]. The reality simulation is an action that aims to form perceptions that tend to be 
false (as if it represents the real reality). It is not necessary that the signs are to have a logical relationship in forming meaning, because with a delusion and the same fantasy, there will be a communication pattern that exists in that space. It has come to the extent that the realities of voters' lives and the self-image of candidates are not related. However, the media make them united in one reality because of the association between the two. People are persuaded and lost without purpose [5].

\section{METHOD}

This study uses a qualitative method that aims to understand the phenomena experienced by research subjects holistically and through descriptions of words and language in specific natural contexts [9]. This method includes the use of the multimodality analyzes (multimodality is a term used for the use of different modalities) [10], together with the use of several semiotic events simultaneously which aim to complement and improve aspects of a study conducted.

\section{FINDINGS}

In Figure 1, the video of Banyu Moto starts with the scene of Dory Harsa as an online motorbike taxi driver who just escorted Nella Kharisma as the passenger. This video clip contains elements of the promotion of online motorbike taxis from the Gojek application, which is currently trending among the Indonesian lower middle class. The existence of Dory Harsa's profession as a Gojek driver implies that the disco-dangdut in the Banyu Moto song is identical to the lower middle class and is not aimed at the upper class.

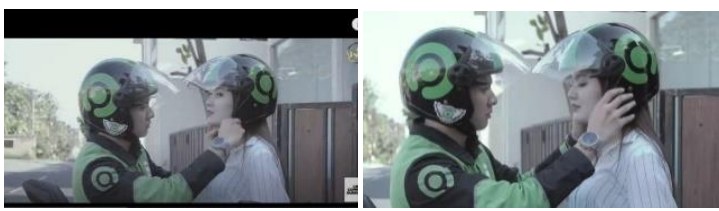

Figure 1 The Opening of the Banyu Moto video clip Depicting Dory's Profession as a Gojek online motorbike taxi driver

In Figure 2 of the Banyu Moto video clip, it tells the story of Dory, a man who had to experience a longdistance love affair with Nella because of her need to of finding work. With a heavy heart, Nella asked Dory's permission to leave him for a while.

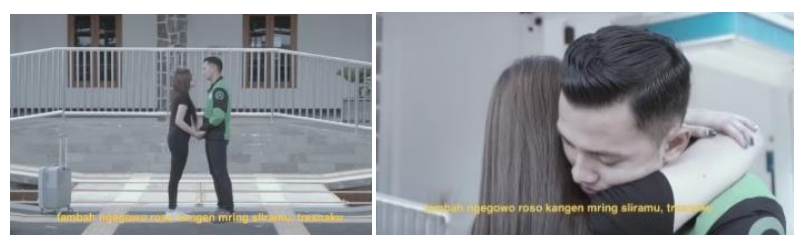

Figure 2 Nella Asking Dory's Permission to Find Work Away from Their Town
In Figure 3, it is told that the long-distance relationship made Dory upset because Nella was too occupied with her work.

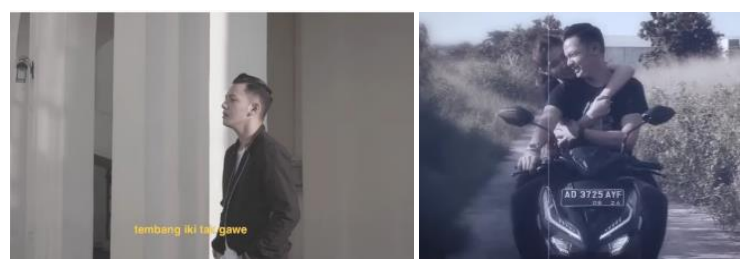

Figure 3 Nella Dory Being Upset upon Nella's Departure

In another part of the video, Dory looked surprised because the bracelet Nella had given to him was missing from his wrist. Then Dory rushed to find the bracelet from his lover.
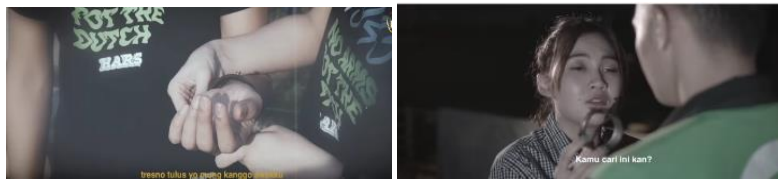

Figure 4 Dory's Lost Bracelet Being Found by Nella

In Picture 4, suddenly, Dory met Nella who was holding the bracelet. At the end of the video clip, there was a conversation between the two that touches the hearts of the audience. "You're looking for this (bracelet), right?" said Nella to Dory. Instead of answering Nella's question, Dory asked about her lover who had returned home without giving any news first. "You said I'm your soulmate? No matter how far I go, I'll definitely come back, "Nella replied with a smile. Stunned, Dory immediately asked for the bracelet. "Where's my bracelet, I will exchange it ...," said Dory who immediately interrupted and Nella said, " for what?". "I exchange it with this (ring)," said Dory Harsa.

\section{DISCUSSION}

The video of the song titled Banyu Moto depicts a duet between two singers of opposite sexes singing a romantic song to each other with passionate acts. The acts are actually a false reality, because it doesn't really happen in real life. As a professional, the acts must be performed in a way that the audience feel that witness a real event. To convince the audience that it is not a false reality, it is necessary to have roles and movements that are more immersive, to make the effect of hyperreality, that is, false realities that appear to be seen as actual realities. Not only giving the singer's movement patterns in the performance, the disco-dangdut music also provides the media with some tricks on the lyrics. A performer is required to be able to explain the meaning of the storyline of the song that is sung, so that the audience will appreciate and be immersed in the story. Even though it is not reality, the storyline in the song looks real, because there are some elements of the actual 
reality in the song, so that the video and song are not merely a false reality. This means that the social reality that occurs in disco-dangdut has been interpreted as something that actually happens.

Hyperreality indicates the emergence of various manipulations of reality that seem more real than the actual reality [1]. The manipulated realities not only seem more real but also more ideal and have more elements than the original one. It is a kind of sublimation that is the process of objects' disappearance from the origins that have settled and is considered normal. Due to the sublimation process, disco-dangdut with its hyperreal elements has become an object or event that is more than just music and entertainment. The capitalists in the dangdut world play a big role in the development of dangdut music in the context of hyperreality.

\section{CONCLUSION}

The development of technology allows producers, in this case the creative arts industry, especially in the art of music (media) in the postmodern era to create elements of hyperreality for singers to help increase their popularity. The public or fans must critically understand which events are realities and the ones that are the results of manipulation by the media. Through this research, it is hoped that the public can have awareness and a more critical mindset towards the world of entertainment so that they can act appropriately in responding to something displayed by the media before knowing the real truth or reality. The results of this study can also be a reference for future researchers to find out and learn more about the development of hyperreality and its relationships in many fields and the benefits of hyperreality for the creative industry which are not limited to increasing popularity but also another range of aspects. Thus, this study as well as future ones can provide positive benefits not only for those involved in the creative industry but also for creative industry consumers themselves.

\section{REFERENCES}

[1] Baudrillard, Jean. Fatal Strategies, tr. by Philip Beitchman and W. G. J. Neisluchowksi. New York: Semiotext, 1990.

[2] Piliang, Yasraf Amir. Sebuah Dunia yang Dilipat: Realitas Kehidupan Menjelang Milenium Ketiga dan Matinya Postmodernisme [A Folded World: The Reality of Life Towards the Third Millennium and the Death of Postmodernism]. Bandung: Mizan, 1998.

[3] Rivers, William L., Jay W. Jensen, and Theodore Peterson. Media Massa dan Masyarakat Modern
[Mass Media and Modern Society]. Jakarta: Prenada Media, 2003.

[4] Best, Steven, and Douglas Kellner. The postmodern adventure: Science technology and cultural studies at the third millennium. Guilford Press, 2001.

[5] Piliang, Yasraf Amir. Transpolitika: Dinamika Politik di Dalam Era Virtualitas [Transpolitics: Political Dynamics in the Era of Virtuality]. Yogyakarta: Jalasutra, 2006

[6] Martadi, Martadi. Reposisi Citra Melalui Logo: Studi Kasus Perubahan Logo PT Pos Indonesia [Reposition of Image Through Logo: Case Study of Change of Logo of PT Pos Indonesia]. Nirmana 4(1), $2002 . \quad$ URL: https://ced.petra.ac.id/index.php/dkv/article/view/1 $\underline{6080}$

[7] Piliang, Yasraf Amir. Hipersemiotika Tafsir Cultural Studies atas Matinya Makna [Hypersemiotics Interpretation of Cultural Studies of the Death of Meaning]. Yogyakarta: Jalasutra, 2010.

[8] Carney, Sean Josep Patrick. Jean Baudrillard "The Precession of Simulacra" Translated from English to American. Continent 2(2), 2012. pp. 99-135.

URL: https://monoskop.org/images/4/41/Continent._2.2.p df

[9] Meleong, Lexy J. Metode Penelitian Kualitatif [Qualitative Research Methods]. Bandung: Remaja Rosdakarya, 2013.

[10] Thuy, Tran Thi Hieu. Reading Images: The Grammar of Visual Design. VNU Journal of Foreign Studies 33(6), 2017. URL: https://js.vnu.edu.vn/FS/article/view/4217/3931 